\title{
Fate of cyanobacterial toxins in the pelagic food web: transfer to copepods or to faecal pellets?
}

\author{
M. Lehtiniemi ${ }^{1, *, * *}$, J. Engström-Öst ${ }^{1, *}$, M. Karjalainen ${ }^{1, *}$, B. Kozlowsky-Suzuki ${ }^{2}$, \\ M. Viitasalo ${ }^{3}$
}

${ }^{1}$ Department of Ecology and Systematics, Division of Hydrobiology, University of Helsinki, PO Box 65, 00014 Helsinki, Finland

${ }^{2}$ Department of Biology and Environmental Sciences, University of Kalmar, Barlasgatan 1, 39182 Kalmar, Sweden

${ }^{3}$ Finnish Institute of Marine Research, PO Box 33, 00931 Helsinki, Finland

\begin{abstract}
Toxic cyanobacterial blooms are a common phenomenon in the Baltic Sea. The fate of the toxin in the food web is largely unknown. We studied the effect of algal diets on production of pellets and toxin content of the calanoid copepod Eurytemora affinis in the northern Baltic Sea. Fieldcollected copepods were fed with (1) cultured toxic cyanobacteria Nodularia spumigena; (2) cultured non-toxic flagellates Brachiomonas submarina; and (3) a natural phytoplankton assemblage. Natural phytoplankton was dominated by non-toxic cyanobacteria Aphanizomenon flos-aquae, but also remnants of toxic $N$. spumigena were found. Pellet production was highest on cultured B. submarina, second highest on $N$. spumigena and lowest on natural phytoplankton. Because pellets were produced on cultured $N$. spumigena, this shows that toxic cyanobacteria are consumed if no other food is available. The toxin content of $E$. affinis was highest in copepods fed with cultured $N$. spumigena, but toxin was also found in lower concentrations in animals fed with natural phytoplankton. Results indicate that an accumulation of toxins mainly occurs during a growing phase of cyanobacterial blooms. The toxin concentration in the pellets was approximately 6 to 12 times lower than in the copepods. We suggest that a large part of the ingested toxin accumulates in copepod tissues, although some is egested with pellets. This may lead to transport and, possibly, accumulation of cyanobacterial toxin in higher pelagic trophic levels in the Baltic Sea.
\end{abstract}

KEY WORDS: Cyanobacterial toxin $\cdot$ Nodularia spumigena $\cdot$ Toxin transfer $\cdot$ Copepods $\cdot$ Faecal pellets

\section{INTRODUCTION}

Cyanobacteria blooms are a common phenomenon in eutrophic lakes and brackish waters around the world. Half of the blooms are either hepatotoxic or neurotoxic (Sivonen \& Jones 1999). Cyanobacterial mass occurrences, dominated by the bundle-forming Aphanizomenon flos-aquae or the hepatotoxic Nodularia spumigena, occur every summer in the Baltic Sea (Sivonen \& Jones 1999, Kankaanpää et al. 2001), and the extent and magnitude of the blooms seem to be increasing (Kahru et al. 1994). The bloom event may

\footnotetext{
* Present address: Finnish Institute of Marine Research, PO Box 33, 00931 Helsinki, Finland

${ }^{* *}$ E-mail: maiju.lehtiniemi@fimr.fi
}

last for days to weeks in an active growth state and toxins are released to the water column when decay begins (Sivonen \& Jones 1999, Kankaanpää et al. 2001). Toxins may enter and accumulate in organisms either via food (ingestion of cyanobacterial cells), drinking water or directly from water (adsorption/absorption of dissolved toxin; Karjalainen et al. unpubl.). Hepatotoxic cyanobacteria are acutely lethal to vertebrates ( $\mathrm{LD}_{50}$ for mice $50 \mathrm{\mu g} \mathrm{kg}^{-1}$; Kuiper-Goodman et al. 1999) and they also have deleterious effects on invertebrates (e.g. Fulton \& Paerl 1987, DeMott et al. 1991, Reinikainen et al. 1994, Sellner et al. 1996, DeMott 1999, Koski et al. 1999a).

During the last $50 \mathrm{yr}$, there have been several cases where dogs or cattle have been killed by a toxic waterbloom in the Baltic Sea (e.g. Persson et al. 1984, 
Sivonen et al. 1990, Nehring 1993). Domestic animals have died by drinking bloom water or by eating toxic cyanobacteria on the shores. However, the ecological effects of toxic algae in the pelagic ecosystem are largely unknown. If the toxins are persistent, like microcystins (Lahti et al. 1997), they may form a health risk via transfer and accumulation in the pelagic food web. In marine and freshwater ecosystems, the transfer of toxins has been suggested to occur via tintinnids (Maneiro et al. 2000), copepods (White 1981, Teegarden \& Cembella 1996, Tester et al. 2000, Turner et al. 2000) or clams (Prepas et al. 1997) to higher trophic levels such as fish, birds or baleen whales. Furthermore, herbivorous zooplankton, after ingesting toxic algae, may produce toxin-containing faecal pellets that either sediment or are consumed by other zooplankton in the water column (Maneiro et al. 2000). This kind of transport of harmful substances via faecal pellets of aquatic organisms has been suggested to happen with pollutants such as heavy metals and radionuclides (reviewed by Turner \& Ferrante 1979).

Zooplankton faecal pellets either sink to deep waters and sediment to the bottom (Turner \& Ferrante 1979, Dagg \& Walser 1986, Fowler et al. 1991), or are recycled in the euphotic zone by other zooplankton (Frankenberg \& Smith 1967, Smetacek 1980, Hofmann et al. 1981, Lampitt et al. 1990, Ayukai \& Hattori 1992, Viitasalo et al. 1999, reviewed by Turner 2002). If toxic pellets are recycled in the mixed layer, toxins may disperse further and accumulate in the pelagic food web. In contrast, if faecal material sediments and benthic animals feed on it prior to decomposition of pellets, toxin may be transported from the pelagic zone to the benthos and accumulate in benthic animals (reviewed by Turner \& Ferrante 1979).

Our aim was to experimentally investigate the fate of cyanobacterial toxin in the pelagic food web by providing herbivorous copepods with different toxic and nontoxic algal suspensions, and by measuring their pellet production and toxin content. We wanted to measure whether toxin accumulates in copepods or is further recycled along with faecal pellet production. Further, we wanted to compare 2 different methods, enzyme-linked immunosorbent assay (ELISA) and a colorimetric protein phosphatase 1A (PP1) inhibition assay, in order to analyse the toxin content in copepods and pellets.

\section{MATERIALS AND METHODS}

Experiments were conducted during a cruise on RV 'Aranda' (Finnish Institute of Marine Research) in August 2000 in the northern Baltic Sea. The copepods and natural phytoplankton for the experiments were collected from Stn F64 (60 $11.34^{\prime}$ N, $19^{\circ} 08.55^{\prime}$ E, depth
294 m), between Åland Islands and Sweden. We collected calanoid copepods Eurytemora affinis (Poppe) for the experiments, because they are one of the most abundant copepod species in the area and are known to feed on cyanobacteria (Koski et al. 1999a, Engström et al. 2000). Copepods were collected with a $200 \mu \mathrm{m}$ mesh-sized WP-2 net by 3 tows from $50 \mathrm{~m}$ depth to the surface. The prevailing water temperature near the surface was $16^{\circ} \mathrm{C}$ and the salinity was $6 \%$.

The copepods were incubated in 3 different food suspensions. We used cultured toxic cyanobacteria Nodularia spumigena (nodularin-producing AV1) and cultured non-toxic green algae Brachiomonas submarina for the incubations. B. submarina was used as a control for good quality food (Koski et al. 1999b). Both cultures were unialgal, but not axenic. N. spumigena was obtained from continuous cultures maintained at the Division of Microbiology, University of Helsinki (Lehtimäki et al. 1994, 2000), and grown in a modified Z8 medium (Hughes et al. 1958, Kotai 1972). B. submarina was obtained from the culture collection of the Tvärminne Zoological Station, University of Helsinki, and grown in a modified Erdschreiber medium (Hällfors \& Hällfors 1992). The third treatment consisted of a natural phytoplankton community (NC), dominated by the non-toxic cyanobacteria Aphanizomenon flos-aquae. NC was taken from the same station as the copepods (Stn F64) and was filtered through a $100 \mu \mathrm{m}$ mesh-sized net to exclude mesozooplankton from the assemblage. Phytoplankton species in the natural community were identified, relative proportions of species were counted under an inverted microscope (Leica DMIRP, 100 $\times$, $200 \times, 400 \times$ ) and their wet weight was calculated according to OY Tiedesofta (Table 1). There was an intensive $N$. spumigena bloom in the sampling area the previous week; therefore, some decayed cells of this species were present in NC incubations.

Table 1. Wet weight and relative proportions of algae present in the natural phytoplankton community used as a treatment in the experiments

\begin{tabular}{|lcc|}
\hline Class & $\begin{array}{c}\text { Wet weight } \\
\left(\mathrm{mg} \mathrm{m}^{-3}\right)\end{array}$ & $\begin{array}{c}\text { Relative } \\
\text { proportions (\%) }\end{array}$ \\
\hline Cyanophyceae & 271.0 & $41.2^{\mathrm{a}}$ \\
Cryptophyceae & 83.0 & 12.6 \\
Dinophyceae & 72.5 & 11.0 \\
Haptophyceae & 17.0 & 2.6 \\
Chrysophyceae & 16.3 & 2.5 \\
Diaptomophyceae & 27.4 & 4.2 \\
Euglenophyceae & 0.7 & 0.1 \\
Prasinophyceae & 168.1 & 25.5 \\
Chlorophyceae & 1.7 & 0.3 \\
Others & 0.5 & 0.1 \\
a96\% of Cyanophyceae were Aphanizomenon flos-aquae \\
\hline
\end{tabular}


Table 2. Particulate carbon and nitrogen contents $\left(\mu \mathrm{g} \mathrm{l}^{-1}\right)$ and $\mathrm{C}: \mathrm{N}$ ratio of food suspensions used in the experiments. Values are mean $\pm \mathrm{SD}$

\begin{tabular}{|lrrr|}
\hline Food suspension & $\begin{array}{r}\text { Carbon content } \\
\left(\mu \mathrm{C}^{-1}\right)\end{array}$ & $\begin{array}{r}\text { Nitrogen content } \\
\left(\mu \mathrm{C} \mathrm{Cl}^{-1}\right)\end{array}$ & C:N ratio \\
\hline Nodularia spumigena & $876.47 \pm 21.39$ & $159.18 \pm 8.18$ & $5.52 \pm 0.43$ \\
Brachiomonas submarina & $1012.64 \pm 58.85$ & $186.08 \pm 1.58$ & $5.44 \pm 0.27$ \\
Natural phytopl. community & $587.14 \pm 23.60$ & $93.27 \pm 1.51$ & $6.29 \pm 0.17$ \\
\hline
\end{tabular}

linear gradient started at $35 \%$ acetonitrile and was increased to $47 \%$ after $12 \mathrm{~min}$. For the natural community, the analysis was longer, in case there were, e.g., microcystins present: the linear gradient started at $35 \%$ acetonitrile and was increased to $65 \%$ over $30 \mathrm{~min}$. Chromatograms were monitored at a fixed wavelength of $238 \mathrm{~nm}$ and UV spectra from 200 to $300 \mathrm{~nm}$. Food suspensions were fil-

Experiments. The experiments were conducted in in situ temperature in $1.18 \mathrm{l}$ bottles. During incubations the bottles were slowly rotating $(0.5 \mathrm{rpm})$ in a plankton wheel to keep the algae homogeneously suspended. We picked egg-carrying females of Eurytemora affinis with a pipette and put them in filtered seawater (Whatman $\mathrm{GF} / \mathrm{F}$ ) for $24 \mathrm{~h}$ before the experiments in order to evacuate their guts.

The experiment consisted of 3 treatments and 5 replicates. We incubated 20 females per bottle for $24 \mathrm{~h}$, and provided them with algal cultures (Nodularia Spumigena: $876.5 \mu \mathrm{g} \mathrm{C}^{-1}$; Brachiomonas submarina: 1012.6 $\mu \mathrm{g} \mathrm{C}^{-1}$ ) and with a natural phytoplankton community (587.1 $\mathrm{g} \mathrm{C} \mathrm{C}^{-1}$ ). Subsequent to the experiment, the water in the bottles was filtered through 100 and $20 \mu \mathrm{m}$ nets to collect copepods and pellets, respectively, for microscopic and toxin analyses. For particulate carbon and nitrogen analyses (Table 2), triplicate samples of the natural community, B. submarina and $N$. spumigena suspensions, were filtered on precombusted (Whatman GF/F) glass fibre filters and dried overnight in a $60^{\circ} \mathrm{C}$ oven. After drying, filters were folded in tinfoil and analysed in a $\mathrm{CN}$ analyser (NA 1500 NC, FISONS Instruments). Pellet number was counted, and their average length and width were measured under a binocular microscope. Pellet volume was calculated assuming pellets to be cylinders with spherical ends (Viitasalo et al. 1999). From each treatment, 200 pellets and various numbers of living copepods were frozen at $-20^{\circ} \mathrm{C}$ for toxin analyses.

Toxin analyses. The nodularin concentration of the food suspensions, possibly including toxins (Nodularia spumigena and the natural community), was analysed using a Hitachi/Merck high-performance liquid chromatography (HPLC) system equipped with an L-7455 photodiode array detector. HPLC was used because it identifies the detected toxins in the sample. The column used was an ODS (3) Phenomenex (4.6 in diameter $\times 250 \mu \mathrm{m}, 5 \mu \mathrm{m}$ particle size); the mobile phase consisted of acetonitrile with $0.1 \% \mathrm{v} / \mathrm{v}$ TFA (trifluoroacetic acid) and Milli-Q water with $0.1 \%$ v/v TFA in a linear

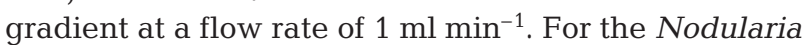
culture, we used a short version of the method described in Lawton et al. (1994) with modifications. The tered onto glass fibre filters (Whatman GF/F) and extracted with $70 \%$ methanol. After bath sonication and centrifugation (14000 rpm, $3 \mathrm{~min}$ ), the supernatant was filtered through $0.2 \mu \mathrm{m}$ pore size PTFE membrane and injected into the HPLC system.

The nodularin concentration of copepods and pellets was analysed with the enzyme-linked immunosorbent assay (ELISA EnviroGard microcystins plate kit) and the colorimetric protein phosphatase 1A (PP1) inhibition assay (Ward et al. 1997, with modifications). The rate of production of $p$-nitrophenol ( $p$ NP) was measured at 2 min intervals for $60 \mathrm{~min}$ at $405 \mathrm{~nm}$ on a Fluostar Microplate Reader (FLUO403) at $37^{\circ} \mathrm{C}$. HPLC was not used in analysing copepod and pellet samples because its detection limit is too high (detection limit $10 \mu \mathrm{g} \mathrm{l}^{-1}$, Harada 1996) for these kinds of samples. Plastic pipette tips and other plastic material were used as little as possible, and glassware was used instead in handling the toxin samples to prevent the adsorption of toxins to plastic surfaces (Metcalf et al. 2000, Hyenstrand et al. 2001). From each treatment, 200 pellets were analysed, and 98 copepods from the Nodularia spumigena treatment (divided into 5 samples), 104 copepods from the natural community (divided into 5 samples) and 23 from Brachiomonas submarina (1 pooled sample as control).

Samples were frozen until analysis. Before analysis, they were freeze-dried for $3 \mathrm{~d}$ in an Edwards Super Modulyo freeze drier. Then samples were extracted

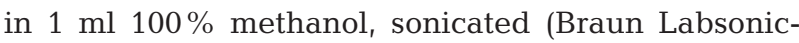
$\mathrm{U})$ for $6 \mathrm{~min}$ in order to homogenise the tissues, and centrifuged for $10 \mathrm{~min}$ at $15000 \mathrm{rpm}$ in an Eppendorf centrifuge $5417 \mathrm{C}$. The supernatant was equally divided for 2 different toxin analyses (ELISA, PP1 inhibition assay) and dried with gaseous nitrogen for 5 min. Dry samples were resuspended in 50\% methanol. They were gradually diluted with Milli-Q water to reach a final concentration of $10 \%$ methanol as high methanol concentrations may give false positive results in the analyses (Metcalf et al. 2000). Of the diluted sample, $100 \mu \mathrm{l}$ was analysed with the ELISA kit and $10 \mu \mathrm{l}$ with PP1 inhibition assay. The concentration of toxin (nodularin) equivalents was calculated per copepod and per number of pellets produced by 1 female during $24 \mathrm{~h}$. 
Pellet production data were analysed with the analysis of covariance (carbon content in the food suspensions was a covariate in the analysis) and Tukey's HSD multiple comparisons test. The differences between copepod toxin concentrations and differences between the ELISA and PP1 inhibition assays were tested with non-parametric tests, because the assumptions for the parametric tests were not met. The Mann-Whitney $U$-test was used because the variances were not different (Kasuya 2001). Statistical analyses were done with the Systat 8.0 version for Windows.

\section{RESULTS}

\section{Pellet production}

The observed pellet production rates were further calculated per carbon concentration in natural community treatment (587.14 $\mu \mathrm{g} \mathrm{C}^{-1}$ ) so the amounts of produced pellets on different food treatments could be compared (Fig. 1). The number of pellets produced by Eurytemora affinis varied significantly between different algal diets (ANCOVA: $F_{2}=23.827, p<0.01$ ) (Table 3). Pellet production was significantly higher in copepods fed with the cultured flagellate Brachiomonas submarina than with cultured toxic Nodularia spumigena (Tukey's HSD: $\mathrm{p}<0.001$ ), or with the natural phytoplankton community ( $\mathrm{p}<0.001)$ (Fig. 1). The difference between pellet numbers produced on $N$. spumigena and the natural community was not significant $(\mathrm{p}>0.05)$. Pellets also differed in size (Table 3$)$. The largest pellets were produced on the natural community and the smallest ones on B. submarina. There was a negative correlation between the number of pel-

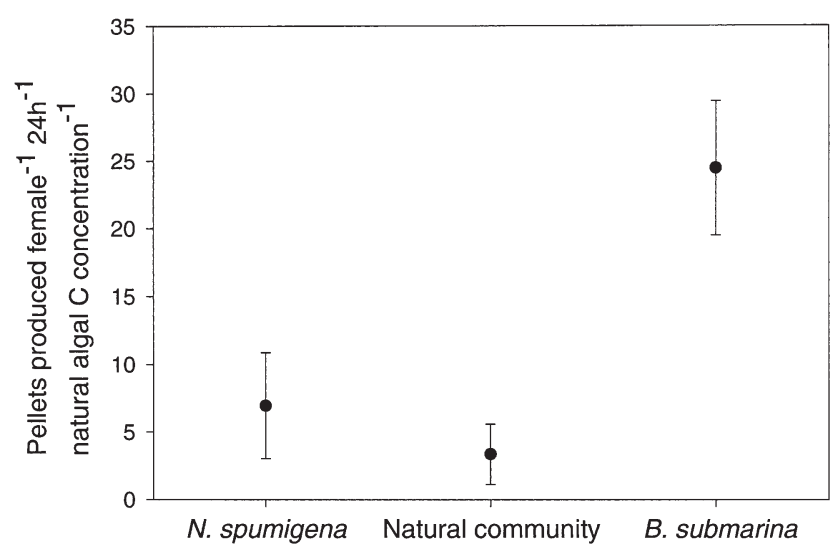

Fig. 1. Eurytemora affinis. Number of faecal pellets produced (mean $\pm \mathrm{SD}$ ) per female calanoid copepod in $24 \mathrm{~h}$ in natural carbon concentration. Copepods were incubated in 3 food suspensions (cultured Nodularia spumigena, natural phytoplankton community and Brachiomonas submarina) lets produced and the pellet volume. Therefore, we calculated a new estimate for total pellet production by multiplying the amount of pellets produced by the pellet volume (Table 3.). However, these results showed the same rank: total pellet production $\left(10^{5}{\mu \mathrm{m}^{3}}^{3}\right.$ female $\mathrm{e}^{-1} \mathrm{~d}^{-1}$ ) was highest on B. submarina, followed by $N$. spumigena and lowest on natural phytoplankton. In addition to differences in size, pellets looked different; the ones produced on B. submarina were dense, compact and very dark greenish, N. spumigena pellets were sticky, quite dark and dense, whereas the ones produced with the natural phytoplankton community were light in colour, loose and dissolved easily.

\section{Toxin in copepods and pellets}

The nodularin concentration in cultured Nodularia spumigena food suspension was $0.85 \mathrm{ng} \mathrm{ml}^{-1}(0.13 \mathrm{pg}$ cell $^{-1}$ ), which corresponds to other measurements on the same species (W. Stolte pers. comm.). The nodularin concentration in the natural phytoplankton was under the detection limit of HPLC. Because toxin was, however, detected in both Eurytemora affinis and in the pellets incubated in NC, it indicates that dissolved nodularin was in the water and not in the phytoplankton cells; there were only a few decayed cells of $N$. spumigena that were measured in toxin analyses. The amount of toxin in copepods prior to the experiments was $\sim 0.0032 \mathrm{ng}$ copepod $^{-1}$ (ELISA) and $0.0095 \mathrm{ng}$ copepod $^{-1}$ (PP1). These are background values and are therefore subtracted from the toxin concentrations measured after the incubations, after which we got the following mean \pm SD measurements with ELISA: 0.031 \pm 0.007 and $0.013 \pm 0.016 \mathrm{ng}$ nodularin equivalents copepod $^{-1}$ fed with $N$. spumigena and the natural community, respectively. The difference between these toxin concentrations was not statistically significant (Mann-Whitney $U$-test: $\mathrm{p}>0.05$ ). The toxin concentration in copepods, measured with PP1 inhibition assay, was $0.101 \pm 0.012 \mathrm{ng}$ copepod $^{-1}$ fed with cultured $N$. spumigena and $0.033 \pm 0.019 \mathrm{ng}$ copepod $^{-1}$ fed with NC. This difference in toxin concentrations between treatments was significantly different (Mann-Whitney $U$-test: $U=4.50, \mathrm{n}_{1}=5, \mathrm{n}_{2}=5, \mathrm{p}<0.05$; Fig. 2).

The values obtained from ELISA were lower than PP1 inhibition assay values, but the difference was not statistically significant (Mann-Whitney $U$-test: $\mathrm{p}$ > 0.05). Although the results of these 2 methods were different, they correlated positively with each other (Spearman correlation: $r_{S}=0.821, n=10, p<0.01$ ), which shows that the trend of the methods is similar. The correlation was calculated for the toxin concentrations of copepods measured with both detection methods. 
Table 3. Eurytemora affinis. Pellet production estimates over $24 \mathrm{~h}$ in 3 different food suspensions, and the length and volume of the pellets. Pellet production is shown in 2 ways: (1) pellets produced female $\mathrm{e}^{-1} \mathrm{~d}^{-1}$; and (2) pellet production is calculated per carbon concentration in natural community treatment $\left(587.14 \mu \mathrm{g} \mathrm{C}^{-1}\right)$, so the pellet production rates on different food treatments can be compared. The total amount of produced pellets was calculated by multiplying pellet production female ${ }^{-1} \mathrm{~d}^{-1}$ in natural carbon concentration with the pellet volume. Values are means $\pm \mathrm{SD}$

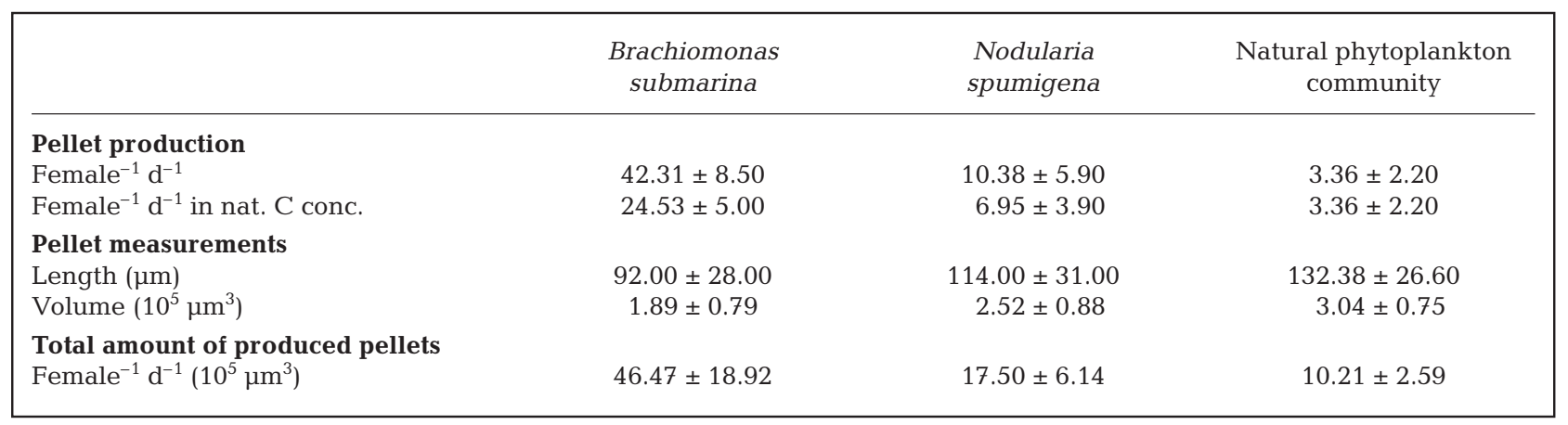

Pellet toxin concentration, measured with ELISA, was on average 0.0067 (Nodularia spumigena) and 0.0026 (NC) ng pellet ${ }^{-1}$ produced by 1 female copepod per day, and $0.0050 \mathrm{ng}$ (N. spumigena) with PP1 inhibition assay. The toxin concentration in pellets produced by a copepod in the natural community was under the detection limit of PP1 inhibition assay (0.5 $\mu \mathrm{g} \mathrm{l^{-1 }}$; Fig. 2).

\section{DISCUSSION}

\section{Pellet production}

Pellets were produced on all 3 diets (cultured Nodularia spumigena, Brachiomonas submarina and natural phytoplankton community). The highest pellet production was observed on $B$. submarina, and this rate is in accordance with earlier findings on pellet production rates of copepods on good food species (on Rhodomonas baltica $\sim 17$ pellets female ${ }^{-1}$, Nejstgaard \& Solberg 1996; on B. submarina 15 pellets and Pseudopedinella elastica $\sim 18$ pellets female ${ }^{-1}$, Koski et al. $1999 b)$. We found low egestion rates on both the natural phytoplankton community and on cultured $N$. spumigena. Low egestion rate on the natural phytoplankton is probably due to the dominance of filamentous Aphanizomenon flos-aquae, which forms large bundles in nature and is therefore inadequate food for zooplankton (e.g. Holm et al. 1983). It has also been shown that aggregates of filamentous $A$. flos-aquae or $N$. spumigena interfere with feeding of zooplankton and, therefore, reduce their feeding rate on other food (Holm et al. 1983, Engström et al. 2001) This is probably another reason for the observed low pellet production in the presence of high numbers of cyanobacterial filaments in our experiments. Low pellet production has also been recorded in Acartia clausi (Nejstgaard \&

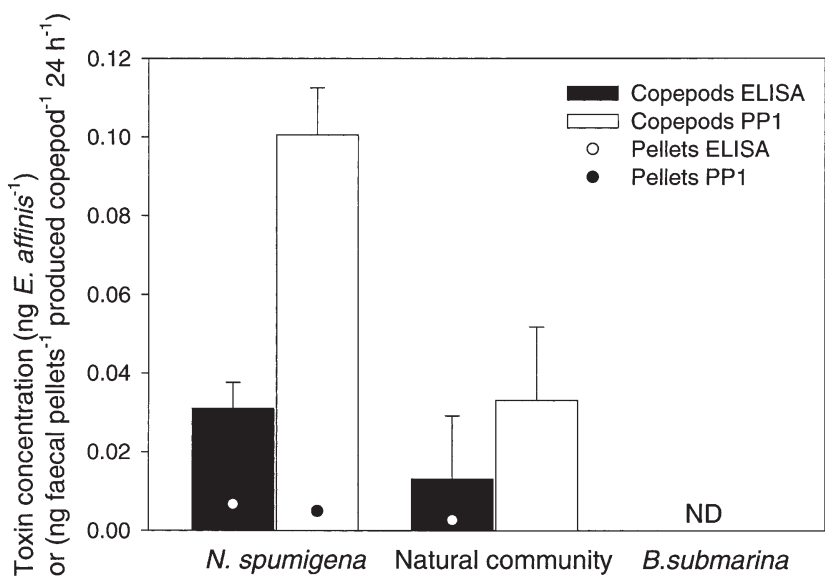

Fig. 2. Eurytemora affinis. Nodularin equivalent concentration of copepods (ng E. affinis ${ }^{-1}$ ) and the faecal pellets (ng faecal pellets ${ }^{-1}$ produced 1 calanoid copepod ${ }^{-1} 24 \mathrm{~h}^{-1}$ ) in 3 different food suspensions (cultured Nodularia spumigena, natural phytoplankton community and Brachiomonas submarina). Toxin concentrations were measured with ELISA and PP1 inhibition assay; see text for further explanations. Toxin was not measurable with PP1 in pellets produced on natural community (nd $=$ not detected). Bars indicate mean values and lines in the end of bars are SD

Solberg 1996) and Eurytemora affinis (Koski et al. 1999b) fed on toxic Prymnesium patelliferum. Egestion rates on toxic diets correspond to egestion rates in filtered seawater, i.e. starvation; thus, low or no pellet production is observed (Huntley et al. 1986). Nevertheless, pellet production was not 0 on any of the offered food suspensions in our experiments, which indicates that E. affinis fed on toxic cyanobacteria to some extent.

Egestion rate decreases with decreasing ingestion rates in copepods (Haney \& Trout 1990, Martens \& Krause 1990). It has been shown that a bloom dominated by Phaeocystis sp., which inhibits copepod feed- 
ing (Hansen \& Boekel 1991), decreased the pellet production of copepods in comparison to the production on a diatom diet (Frangoulis et al. 2001). Toxic Nodularia spumigena is low-quality food for copepods (Sellner et al. 1996, Schmidt \& Jónasdóttir 1997, Koski et al. 1999a), which is in accordance with our findings on low pellet production rates on this species. In contrast, Ianora \& Poulet (1993) suggested that pellet production increases on low-quality diet because bad food can neither be properly assimilated nor transferred into production. Some studies have also suggested that low-quality food may be fed at a high rate to attain enough essential elements and energy for maintenance and growth, i.e. 'compensatory feeding' (e.g. Chen \& Folt 1993, Koski et al. 1998). This, however, requires that the low-quality food item is not rejected before ingestion, as may be the case with many toxic and otherwise inedible food species (Huntley et al. 1986). Our results of low pellet production indicate that $N$. spumigena and Aphanizomenon flos-aquae cannot be used as compensatory food. The reason may be the toxin content or morphology of these cyanobacteria, and therefore they can only be ingested and thus egested at low levels, as shown with many planktonic cyanobacteria species (DeMott \& Moxter 1991).

We noticed that the structure, density, size and colour of the faecal pellets produced varied between diets. This has been shown earlier in several studies (e.g. Dagg \& Walser 1986, Urban et al. 1992, 1993). Our results showed that dense and compact pellets were produced on cultured algae (Brachiomonas submarina and Nodularia spumigena) and loose pellets on natural phytoplankton. The reason is probably that pellets produced at high food concentrations are denser than the ones produced at low food concentrations (Dagg \& Walser 1986). The concentrations of cultured algae were higher than the concentration of the natural phytoplankton in our experiments, which probably affected the pellet density. However, to achieve comparable production rates, we calculated the pellet production per natural algal concentration (Table 3, Fig. 1).

\section{Toxin concentrations}

Eurytemora affinis fed upon toxic algae when there was no other food available. This is in accordance with the study of Koski et al. (1999b) who found that E. affinis fed on the toxic prymnesiophyte Prymnesium patelliferum, both in single-species incubations and in mixtures with other algae. We found cyanobacterial toxin both in copepods and in faecal pellets after $24 \mathrm{~h}$ incubations. Low but measurable concentrations of toxin were also found in copepods incubated in natural phytoplankton. This is possibly due to dissolved toxin in the water, because there were no detectable toxins inside the algal cells in the natural phytoplankton treatment. There was an intensive Nodularia spumigena bloom in the study area $1 \mathrm{wk}$ prior to the cruise, and intracellular nodularin was most probably released from the decayed cyanobacterial cells to the water due to lysis (Sivonen \& Jones 1999). Dissolved hepatotoxins may be detected in the water up to $30 \mathrm{~d}$ after release, as shown with microcystin in a freshwater system (Lahti et al. 1997). We do not know if the toxin was detected inside the copepod (toxin passed the cell membrane) or if the toxins were attached to the surface of the copepod. Nodularin is known to be partly hydrophobic in nature, having a tendency to attach to various surfaces like laboratory materials (Hyenstrand et al. 2001) and thus, it is possible that nodularin was detected from the surface of our experimental animals. In addition, it is possible that nodularin was adsorbed to the surface of some phytoplankton cells in the natural community incubation and that these cells were then ingested by the copepods. Copepods already contained a low concentration of toxin when they were sampled, which supports our suggestions of accumulation of dissolved toxins. However, this background concentration is lower than the ones measured after incubations in the natural phytoplankton, indicating that either copepods may be able to avoid decaying blooms and released toxins in nature, or the dissolved toxin is much more diluted in the sea compared to our incubation bottles, leading to a lower accumulation of toxin.

Dissolved nodularin is shown to accumulate in Baltic ciliates and copepods from the water in $1 \mathrm{~d}$ (Karjalainen et al. unpubl.), which further supports our results. Together with the finding of toxin accumulation by the ingestion of Nodularia spumigena cells, these results of accumulation of dissolved toxin indicate that cyanobacterial toxins are potentially available in nature in both forms (extracellular and intracellular). In the present study, the toxin concentration was much higher in copepods incubated in cultured $N$. spumigena than in the ones incubated in the natural community. This suggests that accumulation of nodularin is more effective by ingestion of toxic cells, compared to the direct adsorption from water. In any case, it is noteworthy that nodularin can be detected in copepods after an intensive bloom, and that toxin was detectable in copepods after as short time as a $1 \mathrm{~d}$ incubation. Reinikainen et al. (2002) showed that dissolved nodularin did not increase the mortality of Eurytemora affinis in $48 \mathrm{~h}$. Therefore, we suggest that dissolved toxin may accumulate in copepods and be transferred in the food web, because they do not cause acute mortality in copepods. However, this route is 
probably not as important as via ingestion of toxic cells, because the concentrations of dissolved toxin were so low in copepods.

The toxin concentration in copepods was many times higher than in the pellets. Pellet production rate depends on food supply (Paffenhöfer \& Knowles 1979, Haney \& Trout 1990). Food supply was saturated during the incubations (>400 $\mu \mathrm{g} \mathrm{C}^{-1}$, e.g. Koski et al. 1999b), to allow continuous feeding and hence, continuous production of faecal pellets during the whole experiment. Therefore, if toxic algae were ingested at a higher rate, it could be possible that the toxin concentration in the egested material would be as high or higher than in the copepods. In this way, toxin could further affect coprophagous animals, which feed on faecal pellets (e.g. Frankenberg \& Smith 1967, Green et al. 1992, Gonzalez \& Smetacek 1994). We found that a small part of the toxin went through the gut into the pellets, whereas a much larger part accumulated in copepods. The toxin concentration in pellets was rather low; therefore, it is unlikely that pellets act as an important vector to coprophagous animals in the pelagic or benthic zone. Most of the pellets in our study area are recycled in the euphotic zone (Viitasalo et al. 1999), which indicates that the small part of toxin that is egested probably remains in the pelagic food chain. The concentrations of toxin in pellets and in copepods incubated in natural phytoplankton were near the detection limits of both ELISA and PP1, indicating that further studies are needed to be certain of the toxin transfer routes after decay of a cyanobacteria bloom. Nevertheless, the main direction of cyanobacterial toxin transfer in the Baltic food web seems to be via herbivorous copepods directly to higher trophic levels, such as mysid shrimps and fish, as suggested previously for various dinoflagellate toxins (White 1981, Teegarden \& Cembella 1996, Tester et al. 2000, Turner et al. 2000), and as suggested by our recent studies (Engström-Öst et al. 2002).

\section{Comparison of toxin detection methods}

The comparison of results from the 2 toxin assays, ELISA and the colorimetric PP1 inhibition assay, showed that they had similar trends (correlation coefficient 0.82), whereas the selectivity/sensitivity of the methods was different. PP1 inhibition assay gave 2.5 to 3.5 times higher toxin concentrations in copepods compared to ELISA, whereas toxin concentrations in pellets were almost on the same level with both methods. This is in accordance with measurements obtained in grazing experiments with Eurytemora affinis: PP1 inhibition assay values were 2 to 5 times higher compared to ELISA (Kozlowsky-Suzuki et al. unpubl.).
ELISA is known to be a more selective method than the PP1 inhibition assay (Honkanen et al. 1995, Harada et al. 1999, Kukkonen 1999). In addition to hepatotoxins, the PP1 inhibition assay also detects other PP1 inhibiting compounds, such as cantharidin, okadaic acid and tautomycin (Ward et al. 1998). This may explain higher toxin concentrations measured with the PP1 inhibition assay compared to ELISA as ELISA seemed to be both more selective and sensitive (detection limit $0.1 \mu \mathrm{g} \mathrm{l}^{-1}$ ) in our study, compared to PP1 inhibition assay (detection limit $0.5 \mathrm{\mu g} \mathrm{l}^{-1}$ ).

Quantification of cyanobacterial toxins is still difficult and different methods often produce different signals on identical samples, as shown in this study. Nevertheless, by comparing different toxin detection methods, results are more reliable. Further, it is important to be certain that the samples contain toxin. When both detection methods give positive results, it is most probable that samples do indeed contain toxins (Honkanen et al. 1995). In our study, positive samples as given by both methods included the copepods fed with cultured Nodularia spumigena or the natural phytoplankton community, and also faecal pellets produced on $N$. spumigena. The toxin concentration in pellets, which were produced on the natural phytoplankton, was under the detection limit of PP1 inhibition assay; thus, these results may not be as reliable as the others.

In conclusion, we suggest that hepatotoxin may accumulate in herbivorous copepods and be transported further in the Baltic pelagic food web, whereas transfer and accumulation of such toxins in the euphotic zone via faecal pellet recycling seems unlikely. The accumulation of nodularin most probably happens via ingestion of toxic cells during a bloom. Further, both toxic and non-toxic filamentous cyanobacteria are considered low quality food; therefore, they are ingested and also egested at low rates. This indicates that during late summer blooms, the food supply for copepods is poor, which probably affects their survival and reproduction negatively.

Acknowledgements. We want to thank the Finnish Institute of Marine Research for the facilities on RV 'Aranda' and the crew for help with sampling. Maija Huttunen is acknowledged for phytoplankton analyses, Harri Kuosa for discussions on experimental set-up, Harri Kankaanpää and Vesa Sipiä for discussions on toxin analyses, and Jorma Kuparinen and 4 anonymous referees for helpful comments on the manuscript. Sari Repka and Kaarina Sivonen provided us with Nodularia spumigena culture and allowed us to use lab facilities during sample processing and toxin analysis. The study was financed by the Academy of Finland, Walter and Andrée de Nottbeck Foundation, Maj and Tor Nessling Foundation, MISTRA (Swedish Foundation for Strategic Environmental Research) and Brazilian National Research Council. 


\section{LITERATURE CITED}

Ayukai T, Hattori H (1992) Production and downward flux of zooplankton fecal pellets in the anticyclonic gyre off Shikoku, Japan. Oceanol Acta 15:163-172

Chen CY, Folt CL (1993) Measures of food quality as demographic predictors in freshwater copepods. J Plankton Res 15:1247-1261

Dagg MJ, Walser E Jr (1986) The effect of food concentration on fecal pellet size in marine copepods. Mar Ecol Prog Ser 31:1066-1071

DeMott W (1999) Foraging strategies and growth inhibition in five daphnids feeding on mixtures of a toxic cyanobacterium and a green alga. Freshw Biol 42:263-274

DeMott W, Moxter F (1991) Foraging on cyanobacteria by copepods: responses to chemical defenses and resource abundance. Ecology 72:1820-1834

DeMott WR, Zhang QX, Carmichael WW (1991) Effects of toxic cyanobacteria and purified toxins on the survival and feeding of a copepod and three species of Daphnia. Limnol Oceanogr 36:1346-1357

Engström J, Koski M, Viitasalo M, Reinikainen M, Repka S, Sivonen K (2000) Feeding interactions of the common copepods Eurytemora affinis and Acartia bifilosa with the cyanobacteria Nodularia sp. J Plankton Res 22:1403-1409

Engström J, Viherluoto M, Viitasalo M (2001) Effects of toxic and non-toxic cyanobacteria on grazing, zooplanktivory and survival of the mysid shrimp Mysis mixta. J Exp Mar Biol Ecol 257:269-280

Engström-Öst J, Lehtiniemi M, Green S, Kozlowsky-Suzuki B, Viitasalo M (2002) Does cyanobacterial toxin accumulate in mysid shrimps and fish via copepods? J Exp Mar Biol Ecol 276:95-107

Fowler SW, Small LF, La Rosa J (1991) Seasonal particulate carbon flux in the coastal northwestern Mediterranean Sea, and the role of zooplankton fecal matter. Oceanol Acta 14:77-86

Frangoulis C, Belkhiria S, Goffart A, Heqo JH (2001) Dynamics of copepod faecal pellets in relation to a Phaeocystis dominated phytoplankton bloom: characteristics, production and flux. J Plankton Res 23:75-88

Frankenberg D, Smith KL (1967) Coprophagy in marine animals. Limnol Oceanogr 12:443-450

Fulton RS, Paerl HW (1987) Toxic and inhibitory effects of the blue-green alga Microcystis aeruginosa on herbivorous zooplankton. J Plankton Res 9:837-855

Gonzalez HE, Smetacek V (1994) The possible role of the cyclopoid copepod Oithona in retarding vertical flux of zooplankton faecal material. Mar Ecol Prog Ser 113:233-246

Green E, Harris R, Duncan A (1992) The production and ingestion of faecal pellets by nauplii of marine calanoid copepods. J Plankton Res 14:1631-1643

Hällfors G, Hällfors S (1992) The Tvärminne collection of algal cultures. In: Pokki J (ed) Tvärminne studies, Vol 5. Yliopistopaino, Helsinki, p 15-17

Haney JF, Trout MA (1990) Relationships between fecal pellet production and feeding in the calanoid copepod Boeckella. J Plankton Res 12:701-716

Hansen FC, Boekel WHM (1991) Grazing pressure of the calanoid copepod Temora longicornis on a Phaeocystis dominated spring bloom in a Dutch tidal inlet. Mar Ecol Prog Ser 78:123-129

Harada KI (1996) Trace analysis of microcystins. Phycology $35: 36-41$

Harada KI, Kondo F, Lawton L (1999) Laboratory analysis of cyanotoxins. In: Chorus I, Bartram J (eds) Toxic cyanobacteria in water. E \& FN Spon, London, p 369-405
Hofmann EE, Klinck JM, Paffenhöfer GA (1981) Concentrations and vertical fluxes of zooplankton fecal pellets on a continental shelf. Mar Biol 61:327-335

Holm NP, Ganf GG, Shapiro J (1983) Feeding and assimilation rates of Daphnia pulex fed Aphanizomenon flosaquae. Limnol Oceanogr 28:677-687

Honkanen RE, Caplan FR, Baker KK, Baldwin CL and 19 others (1995) Protein phosphatase inhibitory activity in extracts of cultured blue-green algae (Cyanophyta). J Phycol 31:478-486

Hughes EO, Gorham PR, Zehnder A (1958) Toxicity of a unialgal culture of Microcystis aeruginosa. Can J Microbiol 4:225-236

Huntley M, Sykes P, Rohan S, Marin V (1986) Chemicallymediated rejection of dinoflagellate prey by the copepods Calanus pacificus and Paracalanus parvus: mechanism, occurrence and significance. Mar Ecol Prog Ser 28:105-120

Hyenstrand P, Metcalf JS, Beattie KA, Codd GA (2001) Losses of the cyanobacterial toxin microcystin-LR from aqueous solution by adsorption during laboratory manipulations. Toxicon 39:589-594

Ianora A, Poulet SA (1993) Egg viability in the copepod Temora stylifera. Limnol Oceanogr 38:1615-1626

Kahru M, Horstman U, Rud U (1994) Satellite detection of increased cyanobacteria blooms in the Baltic Sea: natural fluctuation or ecosystem change? Ambio 23:469-472

Kankaanpää HT, Sipiä VO, Kuparinen JS, Ott JL, Carmichael WW (2001) Nodularin analyses and toxicity of a Nodularia spumigena (Nostocales, Cyanobacteria) water-bloom in the western Gulf of Finland, Baltic Sea, in August 1999. Phycologia 40:268-274

Kasuya E (2001) Mann-Whitney $U$ test when variances are unequal. Anim Behav 61:1247-1249

Koski M, Klein Breteler W, Schogt N (1998) Effect of food quality on rate of growth and development of the pelagic copepod Pseudocalanus elongatus (Copepoda, Calanoida). Mar Ecol Prog Ser 170:169-187

Koski M, Engström J, Viitasalo M (1999a) Reproduction and survival of the calanoid copepod Eurytemora affinis fed with toxic and non-toxic cyanobacteria. Mar Ecol Prog Ser 186:187-197

Koski M, Rosenberg M, Viitasalo M, Tanskanen S, Sjölund U (1999b) Is Prymnesium patelliferum toxic for copepods? Grazing, egg production, and egestion of the calanoid copepod Eurytemora affinis in mixtures of 'good' and 'bad' food. ICES J Mar Sci 56(Suppl):131-139

Kotai J (1972) Instructions for preparation of modified nutrient solution Z8 for algae. Norwegian Inst Water Res Oslo B11(69):1-5

Kuiper-Goodman T, Falconer I, Fitzgerald J (1999) Human health aspects. In: Chorus I, Bartram J (eds) Toxic cyanobacteria in water. E \& FN Spon, London, p 113-153

Kukkonen J (1999) Syanobakteerien maksatoksiinien osoitusmenetelmien vertailu. (Comparison of cyanobacterial detection methods). The Finnish environment, Vol 332. Edita, Finland (in Finnish with English summary)

Lahti K, Rapala J, Färdig M, Niemelä M, Sivonen K (1997) Persistence of cyanobacterial hepatotoxin, microcystin-LR in particulate material and dissolved in lake water. Water Res 31:1005-1012

Lampitt RS, Noji T, Bodungen BV (1990) What happens to zooplankton faecal pellets? Implications for material flux. Mar Biol 104:15-23

Lawton LA, Edwards C, Codd GA (1994) Extraction and highperformance liquid chromatography method for the determination of microcystins in raw and treated water. Analyst 119:1525-1530 
Lehtimäki J, Sivonen K, Luukkainen R, Niemelä S (1994) The effects of incubation time, temperature, light, salinity, and phosphorus on growth and hepatotoxin production of Nodularia strains. Arch Hydrobiol 130:269-282

Lehtimäki J, Lyra C, Suomalainen S, Sundman P, Rouhiainen L, Paulin L, Salkinoja-Salonen M, Sivonen K (2000) Characterization of Nodularia strains, cyanobacteria from brackish waters, by genotypic and phenotypic methods. Int J Syst Evol Microbiol 50:1043-1053

Maneiro I, Frangópulos M, Guisande C, Fernández M, Reguera B, Riveiro I (2000) Zooplankton as a potential vector of diarrhetic shellfish poisoning toxins through the food web. Mar Ecol Prog Ser 201:155-163

Martens P, Krause M (1990) The fate of faecal pellets in the North Sea. Helgol Wiss Meeresunters 44:9-19

Metcalf JS, Hyenstrand P, Beattie KA, Codd GA (2000) Effects of physicochemical variables and cyanobacterial extracts on the immunoassay of microcystin-LR by two ELISA kits. J Appl Microbiol 89:532-538

Nehring S (1993) Mortality of dogs associated with a mass development of Nodularia spumigena (Cyanophyceae) in a brackish lake at the German North Sea coast. J Plankton Res 15:867-872

Nejstgaard JC, Solberg PT (1996) Repression of copepod feeding and fecundity by the toxic haptophyte Prymnesium patelliferum. Sarsia 81:339-344

Paffenhöfer GA, Knowles SC (1979) Ecological implications of fecal pellet size, production and consumption by copepods. J Mar Res 37:35-49

Persson PE, Sivonen J, Keto K, Kononen K, Niemi M, Viljamaa $\mathrm{H}$ (1984) Potentially toxic blue-green algae (cyanobacteria) in Finnish natural waters. Aqua Fenn 14:147-154

Prepas EE, Kotak BG, Campbell LM, Evans JC, Hrudey SE, Holmes CFB (1997) Accumulation and elimination of cyanobacterial hepatotoxins by the freshwater clam Anodonta grandis simpsoniana. Can J Fish Aquat Sci 54: $41-46$

Reinikainen M, Ketola M, Walls M (1994) Effects of the concentrations of toxic Microcystis aeruginosa and an alternative food on the survival of Daphnia pulex. Limnol Oceanogr 39:424-432

Reinikainen M, Lindvall F, Meriluoto JAO, Repka S, Sivonen K, Spoof L, Wahlsten M (2002) Effects of dissolved cyanobacterial toxins on the survival and egg hatching of estuarine calanoid copepods. Mar Biol 140:577-583

Schmidt K, Jónasdóttir SH (1997) Nutritional quality of two cyanobacteria: how rich is 'poor' food? Mar Ecol Prog Ser 151:1-10

Sellner KG, Olson MM, Olli K (1996) Copepod interactions with toxic and non-toxic cyanobacteria from the Gulf of Finland. Phycologia 35(Suppl):177-182

Sivonen K, Jones G (1999) Cyanobacterial toxins. In: Chorus I, Bartram J (eds) Toxic cyanobacteria in water. E \& FN Spon, London, p 41-111

Sivonen K, Kononen K, Carmichael WW, Dahlem AM, Rinehart KL, Kiviranta J, Niemelä SI (1989a) Occurrence of the hepatotoxic cyanobacterium Nodularia spumigena in the

Editorial responsibility: Otto Kinne (Editor),

Oldendorf/Luhe, Germany
Baltic Sea and structure of the toxin. Appl Environ Microbiol 55:1990-1995

Sivonen K, Kononen K, Esala AL, Niemelä SI (1989b) Toxicity and isolation of the cyanobacterium Nodularia spumigena from the southern Baltic Sea in 1986. Hydrobiologia 185: $3-8$

Sivonen K, Niemelä SI, Niemi RM, Lepistö L, Luoma TH, Räsänen LA (1990) Toxic cyanobacteria (blue-green algae) in Finnish fresh and coastal waters. Hydrobiologia 190:267-275

Smetacek VS (1980) Zooplankton standing stock, copepod faecal pellets and particulate detritus in Kiel Bight. Estuar Coast Mar Sci 11:477-490

Teegarden GJ, Cembella AD (1996) Grazing of toxic dinoflagellates, Alexandrium spp., by adult copepods of coastal Maine: implications for the fate of paralytic shellfish toxins in marine food webs. J Exp Mar Biol Ecol 196:145-176

Tester PA, Turner JT, Shea D (2000) Vectorial transport of toxins from the dinoflagellate Gymnodinium breve through copepods to fish. J Plankton Res 22:47-61

Turner JT (2002) Zooplankton fecal pellets, marine snow and sinking phytoplankton blooms. Aquat Microb Ecol 27: $57-102$

Turner JT, Ferrante JG (1979) Zooplankton fecal pellets in aquatic ecosystems. BioScience 29:670-677

Turner JT, Doucette GJ, Powell CL, Kulis DM, Keafer BA, Anderson DM (2000) Accumulation of red tide toxins in larger size fractions of zooplankton assemblages from Massachusetts Bay, USA. Mar Ecol Prog Ser 203:95-107

Urban JL, McKenzie CH, Deibel D (1992) Seasonal differences in the content of Oikopleura vanhoeffeni and Calanus finmarchicus faecal pellets: illustrations of zooplankton food web shifts in coastal Newfoundland waters. Mar Ecol Prog Ser 84:255-264

Urban JL, Deibel D, Schwinghamer P (1993) Seasonal variations in the densities of fecal pellets produced by Oikopleura vanhoeffeni (C. Larvacea) and Calanus finmarchicus (C. Copepoda). Mar Biol 117:607-613

Viitasalo M, Rosenberg M, Heiskanen AS, Koski M (1999) Sedimentation of copepod fecal material in the coastal northern Baltic Sea: where did all the pellets go? Limnol Oceanogr 44:1388-1399

Ward CJ, Beattie KA, Lee EYC, Codd GA (1997) Colorimetric protein phosphatase inhibition assay of laboratory strains and natural blooms of cyanobacteria: comparisons with high-perfomance liquid chromatographic analysis for microcystins. FEMS Microbiol Lett 153:465-473

Ward CJ, Lee EYC, Beattie KA, Codd GA (1998) Colorimetric protein phosphatase inhibition assay for microcystins and nodularin in laboratory cultures and natural blooms of cyanobacteria. In: Reguera B, Blanco J, Fernández ML, Wyatt $\mathrm{T}$ (eds) Harmful algae. Xunta de Galicia and Intergovernmental Oceanographic Commission of UNESCO, Paris. Grafisant, Santiago de Compostela, p 541-544

White AW (1981) Marine zooplankton can accumulate and retain dinoflagellate toxins and cause fish kills. Limnol Oceanogr 26:103-109

Submitted: November 19, 2001; Accepted: June 6, 2002 Proofs received from author(s): September 3, 2002 